Article

\title{
Springback Prediction of a Hot Stamping Component Based on the Area Fractions of Phases
}

\author{
Xiangji Li ${ }^{1,2}$, Xu Yan ${ }^{1}$ and Zhiqiang Zhang ${ }^{1, *}$ \\ 1 Key Laboratory of Automobile Materials, Ministry of Education and College of Materials Science and \\ Engineering, Jilin University, Changchun 130025, China; xjli@jlu.edu.cn (X.L.); yanxu_jlu@sina.com (X.Y.) \\ 2 Rolling Forging Research Institute, Jilin University, Changchun 130025, China \\ * Correspondence: zhangzq@jlu.edu.cn; Tel./Fax: +86-431-85334969
}

Received: 31 May 2019; Accepted: 14 June 2019; Published: 20 June 2019

\begin{abstract}
Different from traditional hot stamping components with full martensite, the new tailored hot stamping (THS) components have different quenched microstructures, which results in their lower shape accuracy. To investigate the influence of different quenched phases on the springback of a component, a THS experiment of a U-shaped component was performed with segmented heating and a cooling tool. The area fractions of phases at different tool temperatures were obtained by a two-stage color tint etching procedure. Results showed that the quenched phase of the cold zone was almost full martensite. The area fraction of martensite in the hot zone was reduced to the lowest $13 \%$ at the tool temperature of $600{ }^{\circ} \mathrm{C}$, while the bainite content reached the highest at $70 \%$. The springback angles at different tool temperatures for quenching were measured by 3D scanning technology and the reverse modeling method. It was revealed that the springback angle increased with the increase of martensite and yet decreased with the increase of bainite. The relationship between the springback angle and the area fractions of the quenched phases was established by means of multiple linear regression analyses. The error analysis results of the predictions and measurements showed that the springback analysis model, based on the area fractions of quenched phases, could be used to predict the springback of hot stamping components with tailored properties.
\end{abstract}

Keywords: boron steel; tailored hot stamping; phase transition; springback

\section{Introduction}

The demand for vehicle weight reduction and improved crash performance has led to the application of hot stamping of boron steel [1,2]. However, the components with high strength and low levels of ductility did not show a good performance in crash energy absorption $[3,4]$. To improve the energy absorption, tailored hot stamping (THS) components with tailored mechanical properties have been developed [5-8]. From continuous cooling transformation (CCT) curve, it can be seen that ferrite and bainite can be obtained at cooling rates lower than $30^{\circ} \mathrm{C} / \mathrm{s}[9,10]$. Since the temperatures of two contact bodies will affect their cooling rates, THS with segmented heating and cooling tools can be used to obtain a multiphase quenched microstructure and achieve the components with tailored properties. There are some studies that analyze how the tool temperature affects the mechanical properties [11-13]. However, the temperature difference between the cooling tool and the heating tool is much larger when the tool is partitioned for cooling and heating, which makes the springback of the formed components more serious than conventional hot stamping. Some scholars have studied the influence of hot stamping process parameters on the springback of formed components [14-16]. They concluded that the springback of the formed component gradually decreased with the increase of blank temperature and holding time. However, for THS components with various quenching phases, the microstructure distribution has an important impact on the springback. 
The springback measurement of components is a complicated process. In order to understand the effect of the quenching phase content on the component springback, a THS experiment was carried out in this paper, and the quenching phase was quantitatively measured by the color metallography and image recognition method. The springback angles of different phase contents were obtained by non-contact 3D measurement. The relationship between phase content and the springback angle was established, which can be used for the determination of the springback of THS components.

\section{Experimental Study}

\subsection{THS Experiments}

Usibor1500P boron steel with a thickness of $1 \mathrm{~mm}$ was used in the experiments, and the chemical composition is shown in Table 1. Figure 1 shows the THS experimental apparatus. The tool material used for this study was H13 steel and did not have any surface or hardening treatments. H13 steel has excellent comprehensive mechanical properties and high anti-tempering stability and is a common material for hot stamping tools. Cooling channels were machined inside the cooling tool to take away the heat of the blank by the water in the channels. Through installing the electric cartridge heaters controlled by the PID system, the hot tool temperatures could be varied from $25^{\circ} \mathrm{C}$ and $600{ }^{\circ} \mathrm{C}$. An air gap of $2 \mathrm{~mm}$ was left between the heating tool and the cooling tool to prevent heat transfer between them.

Table 1. Chemical composition of Usibor 1500P (wt.\%).

\begin{tabular}{ccccccccccc}
\hline $\mathbf{C}$ & $\mathbf{M n}$ & $\mathbf{B}$ & $\mathbf{S i}$ & $\mathbf{P}$ & $\mathbf{C u}$ & $\mathbf{N i}$ & $\mathbf{C r}$ & $\mathbf{A l}$ & $\mathbf{T i}$ & Mo \\
\hline 0.22 & 1.23 & 0.004 & 0.25 & 0.008 & 0.03 & 0.02 & 0.20 & 0.03 & 0.037 & $<0.02$ \\
\hline
\end{tabular}

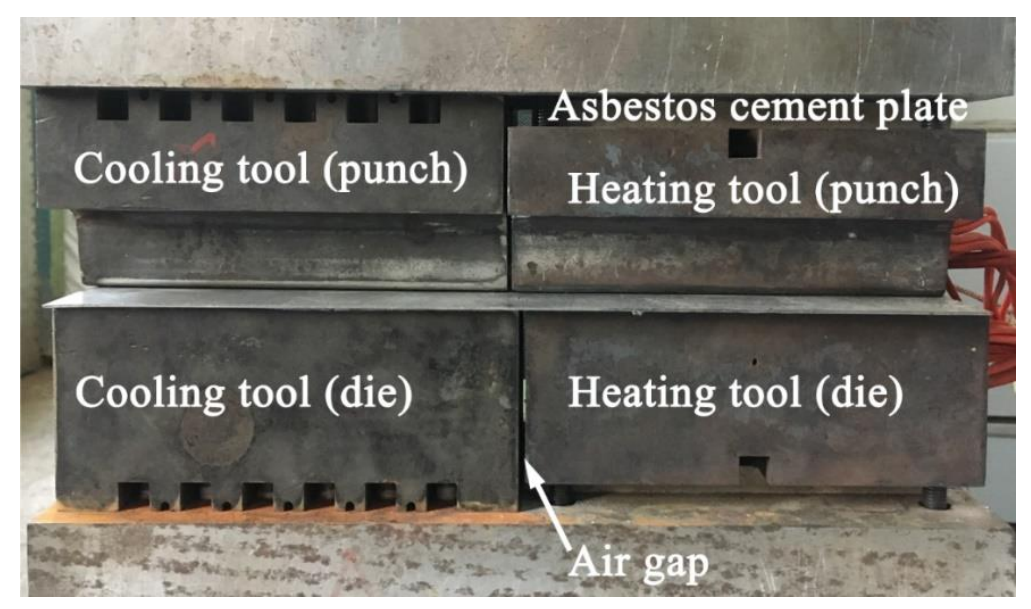

Figure 1. Schematic of the experimental apparatus.

A furnace was used to heat the blank to the temperature of $930^{\circ} \mathrm{C}$ for austenizing, and the heating time was about $5 \mathrm{~min}$. After the blank was austenized, it was moved to the tool to be formed and quenched. It took about $10 \mathrm{~s}$ to move the hot blank from the furnace to the tools. The quenching time was $10 \mathrm{~s}$ with the press force of $400 \mathrm{kN}$.

\subsection{Metallography}

Figure 2 shows the locations of microstructure observation. $\mathrm{C}$ represents the cold zone and $\mathrm{H}$ is the hot zone. To identify and measure the content of the quenched phases, the specimens were mounted in epoxy resin, ground, and polished to a mirror finish, using 400, 1000, and 2000 grit SiC paper, followed by metallographic grinding paste. Two-stage color tint etching with $4 \%$ picral solution and $10 \%$ aqueous sodium metabisulfite solution was used to observe the quenched phases. After 
two-stage etching, the martensite was brown, the bainite was black, and the ferrite was white with an optical microscope. Martensite, bainite, and ferrite were manually set as green, red, and blue, respectively, by ImagePro Plus 7.0 software (Media Cybernetics, Inc., Rockville, MD, USA). The area fractions of quenched phases were quantified.

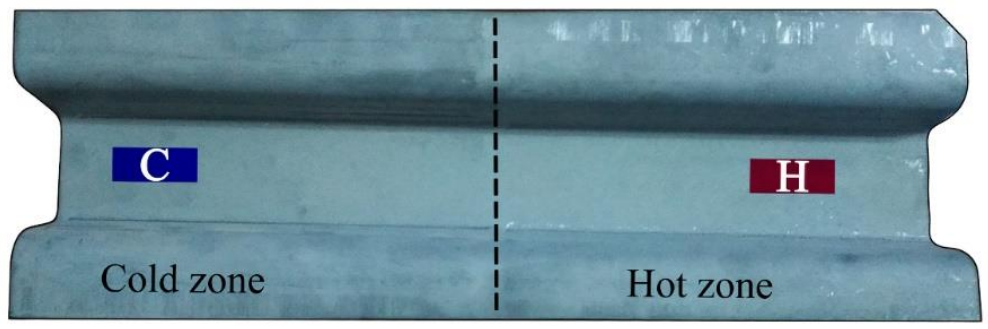

Figure 2. The cutting locations of specimens.

\subsection{Springback Measurement}

The springback measurement process is shown in Figure 3. The 3D scanning of the formed component was first conducted by a PRO CMM3500 optical coordinate measuring machine (NDI International, Waterloo, ON, Canada) and the point cloud data were obtained and processed by PolyWorks software (InnovMetric Software inc, Québec, Canada). By conducting calibration and alignment between polygon data and the original model of the component, the springback angle of the formed component could be accurately measured.

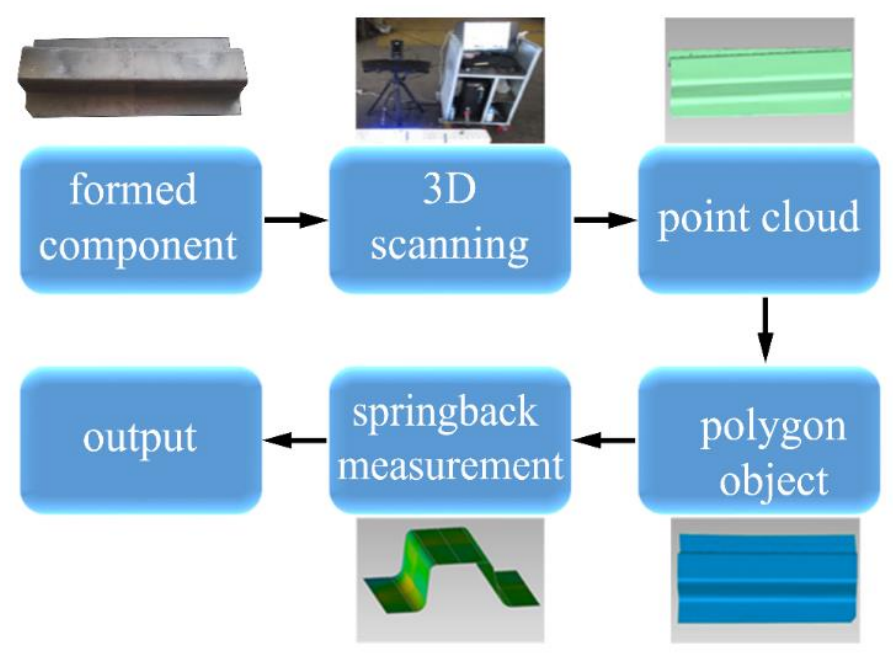

Figure 3. Flowchart of the springback measurement process.

Figure 4 shows the scheme of springback angle measurement. The outer contour and the inner contour are the cross sections of the formed component and the original component, respectively. $\theta_{2}$ is the sidewall angle of the formed component and $\theta_{1}=20^{\circ}$ is the original angle. $\theta_{2}-\theta_{1}$ was defined as a springback angle. 


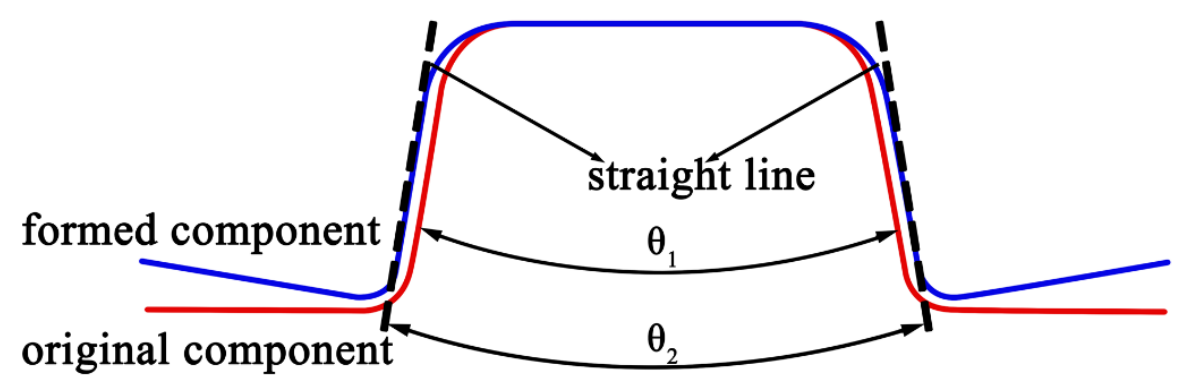

Figure 4. The schematic of the springback angle measurement.

\section{Results and Discussion}

\subsection{Quenched Phases Analysis}

Figure 5 displays color metallography of the formed component quenched at different tool temperatures and micrographs, calibrated by Image Pro Plus 7.0. It can be found that the quenched phases of the cold zone are almost full martensite at heating tool temperatures of $25^{\circ} \mathrm{C}$ and $600{ }^{\circ} \mathrm{C}$, which indicates that the heating tool temperature has little effect on the quenched phases of the cold zone. This may be because the cooling rate of the blank in the cold zone is greater than $100{ }^{\circ} \mathrm{C} / \mathrm{s}, \mathrm{much}$ higher than the critical speed of martensite transformation. However, the occurrence of a small amount of ferrite and bainite in the cold zone may be caused by the large plastic deformation of the U-shape component during the forming $[17,18]$. Martensite decreases, while ferrite and bainite increase in the hot zone with the increase of the tool temperature. When the tool temperature is higher than $200{ }^{\circ} \mathrm{C}$, the area fraction of martensite drops dramatically and reaches $13 \%$ at the tool temperature of $600{ }^{\circ} \mathrm{C}$. The reason may be that the start transformation temperature of martensite is $405^{\circ} \mathrm{C}$ [19] and when the isothermal quenching temperature is higher than the start transformation temperature of martensite, bainite phase transition occurs during continuous cooling, resulting in the decrease of martensite. When quenched at the tool temperature from $300{ }^{\circ} \mathrm{C}$ to $600{ }^{\circ} \mathrm{C}$, the area fraction of bainite increases with the increase of the tool temperature and is close to $70 \%$ at the tool temperature of $600{ }^{\circ} \mathrm{C}$. The isothermal quenching for $10 \mathrm{~s}$ at this temperature range, which is the transition temperature range of bainite [19], results in the rapid formation and the increase of bainite. Shipway et al. [20] have also showed that bainite transition is more likely to occur than martensite transition during the isothermal quenching at this temperature range. With the increase of the tool temperature, ferrite increases slightly. George et al. [21] have demonstrated that the area fraction of ferrite is less than $10 \%$ at the tool temperature of $400{ }^{\circ} \mathrm{C}$, which was close to the $9 \%$ ferrite in this paper. However, George et al. did not make research on the tool temperature higher than $400^{\circ} \mathrm{C}$. The studies in this paper showed that the area fraction of ferrite was $17 \%$ at the tool temperature of $600{ }^{\circ} \mathrm{C}$. 


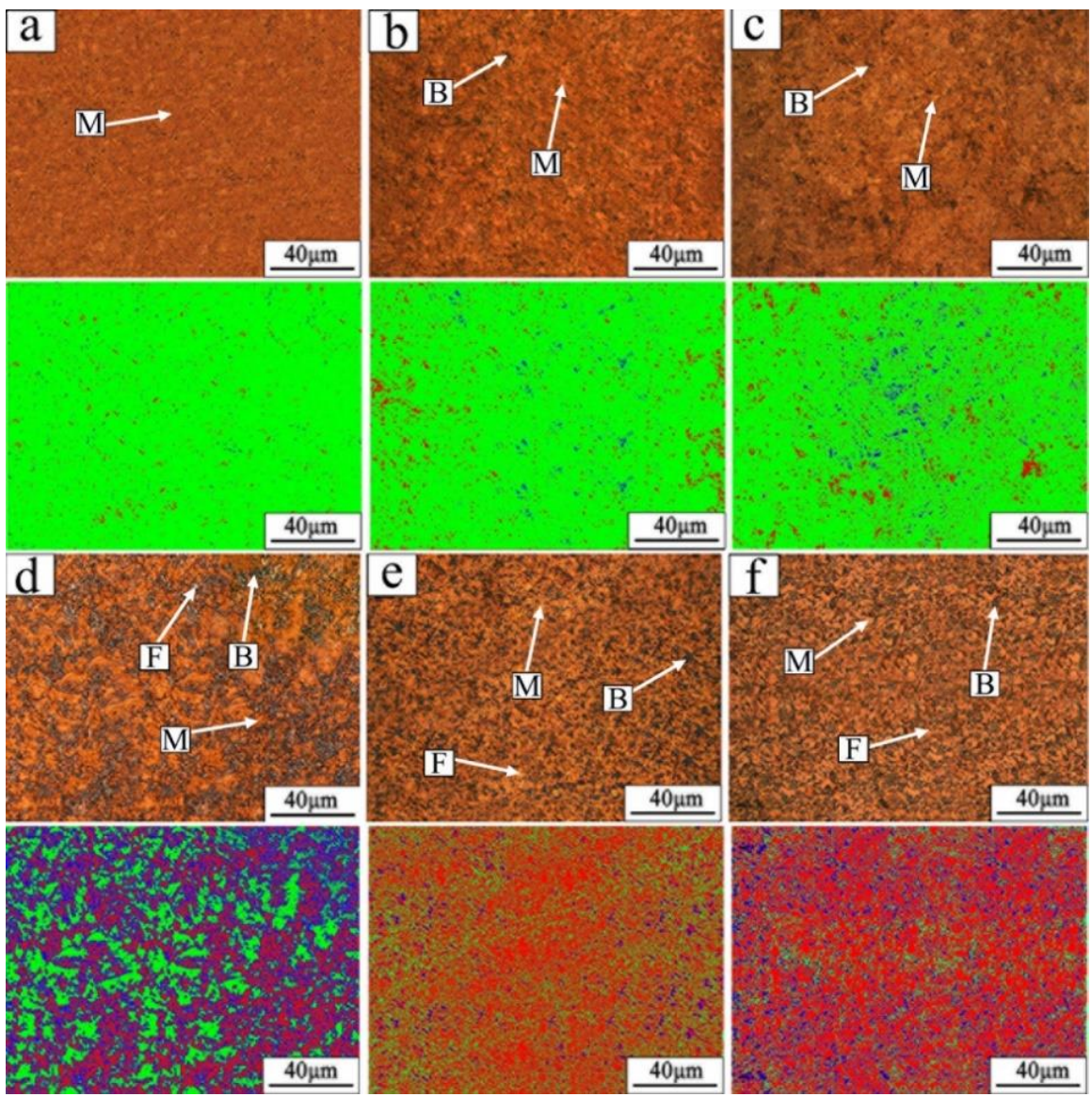

Figure 5. Two-stage color tint etched optical micrographs and manually identified microstructure images (a) $25 \mathrm{C}$; (b) $600 \mathrm{C}$; (c) $200 \mathrm{H}$; (d) $400 \mathrm{H}$; (e) $500 \mathrm{H}$; (f) $600 \mathrm{H}$. C represents the cold zone and H is the hot zone.

\subsection{Springback Results}

Springback angles under different heating tool temperatures are presented in Figure 6. No matter how the tool temperature changes in the hot zone, the spingback angles in the cold zone are almost unchanged. The reason is that the materials in the cold zone have almost the same temperature history and almost full martensite and, thus, the internal stress releases caused by phase transformation expansion and transformation plasticity are almost consistent [22]. The springback angle of the hot zone decreases with the increase of the tool temperature. When the tool temperature is higher than $300^{\circ} \mathrm{C}$, the springback angle decreases and becomes almost stable at the tool temperature higher than $550^{\circ} \mathrm{C}$. According to the relationship between the area fractions of phases and tool temperatures, it can be seen that martensite begins to decrease at the tool temperature higher than $300{ }^{\circ} \mathrm{C}$ and bainite increases dramatically. According to Åkerström and Oldenburg [23], the hardness of martensite and bainite is $510 \mathrm{HV}$ and $402 \mathrm{HV}$, respectively. The decrease of the springback angle in the hot zone is due to the increase of softer bainite. When the tool temperature is higher than $550{ }^{\circ} \mathrm{C}$, the area fractions of martensite and bainite are almost stable and, thus, there is no obvious change in the springback angle.

The relationship between the springback angle and the area fractions of martensite, bainite, and ferrite at different tool temperatures are shown in Figure 7. It can be seen that different quenched phases and their contents, caused by different tool temperatures, have great influence on the springback of the components. The springback angle shows a positive linear correlation with martensite and a negative linear correlation with bainite and ferrite. The correlation coefficient indicates that there is a noticeable linear correlation between them. With the springback angle as the dependent variable and the area fractions of martensite, bainite, and ferrite as the independent variable, a multiple linear 
regression analysis was carried out and the goodness of the fit, R-squared value is 0.985 . The results show that there is a strong linear relationship between the springback angle and the area fractions of martensite, bainte, and ferrite. By the multi-step iterative optimization method, the relationship between the springback angle and the area fractions of quenched phases was established and is shown as Equation (1).

$$
\lambda=3.233 \times\left(0.0469 f_{\mathrm{M}}+0.0439 f_{\mathrm{B}}+0.0005 f_{\mathrm{F}}\right)-12.1286
$$

where $\lambda$ is the springback angle and $f_{\mathrm{M}}, f_{\mathrm{B}}$, and $f_{\mathrm{F}}$ are the area fractions of martensite, bainite, and ferrite, respectively.

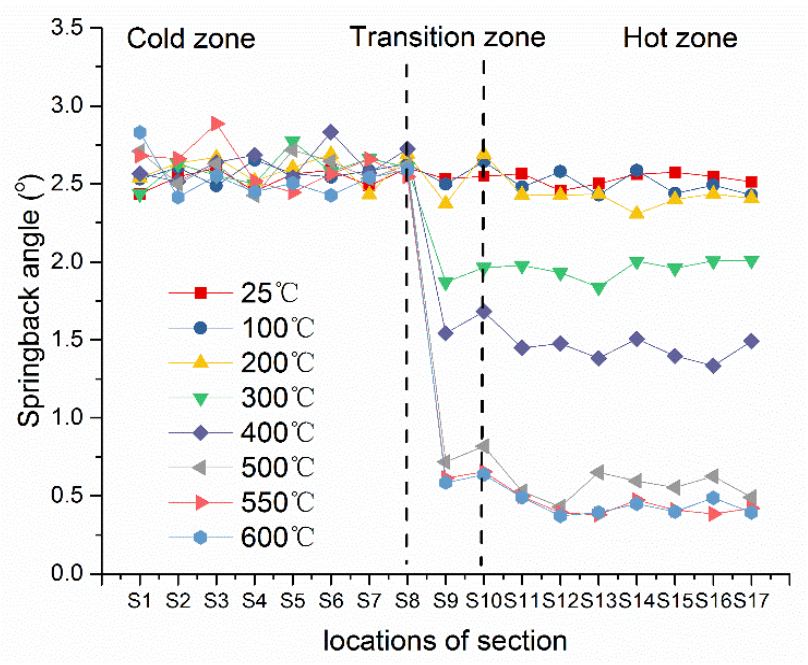

Figure 6. Springback angles under different heating tool temperatures.
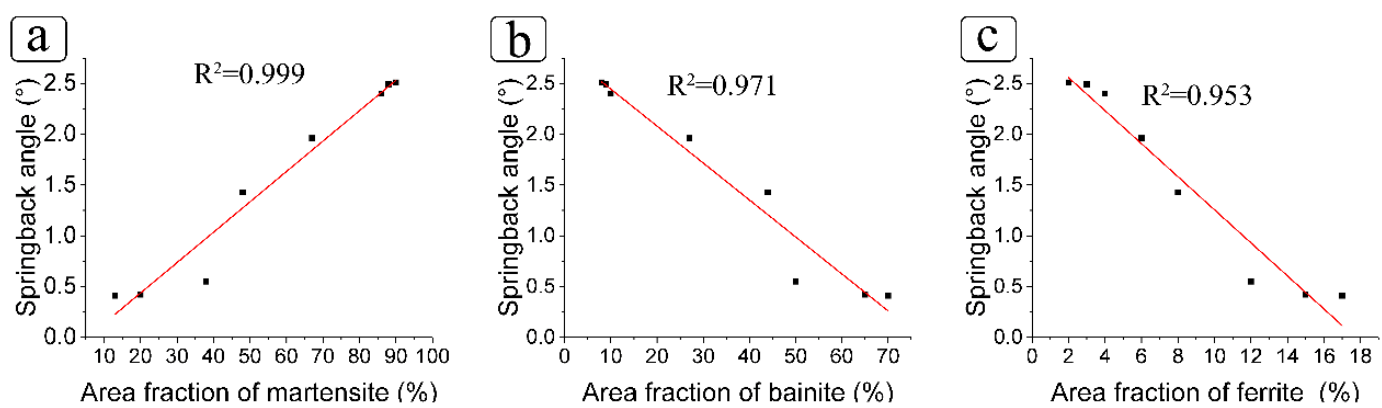

Figure 7. The relationship between the springback angle and area fractions of the quenched phases.

The springback angles calculated by Equation (1) at different heating tool temperatures are given in Table 2. It is found that the maximum relative error is $7.32 \%$ and the angle difference is $0.04^{\circ}$, which indicates that this equation can be used to accurately predict the springback of the formed component, based on the area fractions of the quenched phases. It is worth noting that Equation (1) is the relationship between the phase content and the springback angle, and the change of the tool geometry will lead to the change of the phase content, so after the tool geometry changes, Equation (1) is still applicable. In addition, Equation (1) is obtained in the range of ferrite content less than $20 \%$ and bainite content less than $80 \%$, and if the phase content is beyond the range, it needs to be further verified. 
Table 2. The average springback angle under different heating tool temperatures.

\begin{tabular}{ccc}
\hline Heating Tool Temperature $\left({ }^{\circ} \mathbf{C}\right)$ & Measured Value $\left({ }^{\circ}\right)$ & Calculated Value $\left({ }^{\circ}\right)$ \\
\hline 25 & 2.51 & 2.65 \\
100 & 2.49 & 2.49 \\
200 & 2.40 & 2.33 \\
300 & 1.96 & 1.86 \\
400 & 1.43 & 1.40 \\
500 & 0.55 & 0.59 \\
550 & 0.42 & 0.45 \\
600 & 0.41 & 0.41 \\
\hline
\end{tabular}

\section{Conclusions}

The hot stamping experiment of the U-shaped component was performed with segmented heating and a cooling tool. The relationship between the springback angle and the area fractions of martensite, bainite, and ferrite at different tool temperatures was obtained. The conclusions are as follows:

(1) The quenched microstructure of the cold zone was almost full martensite. The quenched microstructure of the hot zone changed greatly with increasing heating tool temperature. The area fraction of martensite dropped dramatically at heating tool temperatures higher than $200^{\circ} \mathrm{C}$. When the heating tool temperature was $600{ }^{\circ} \mathrm{C}$, martensite dropped to $13 \%$ and bainite increased to $70 \%$. Ferrite gradually increased at temperatures ranging from $25^{\circ} \mathrm{C}$ to $600^{\circ} \mathrm{C}$ and its maximum was close to $17 \%$.

(2) The springback angle of the cold zone was large and remained unchanged with the increase of the heating tool temperature. When the heating tool temperature was higher than $300{ }^{\circ} \mathrm{C}$, the springback angle of the hot zone decreased significantly. The springback angle was minimum and the change of it tended to be stable with the heating tool temperature over $550{ }^{\circ} \mathrm{C}$.

(3) The relationship between the area fractions of quenched phases and the springback angle was established by the optimization method. A relative error analysis revealed that the relationship could be used to accurately predict the springback of a tailored formed hot stamped component.

Author Contributions: X.L. conceived and designed the experiments; X.Y. performed the experiments; Z.Z. polished the writing and grammar.

Funding: This work was supported by National Natural Science Foundation of China (51205162 and 51275203).

Conflicts of Interest: The authors declare no conflict of interest.

\section{References}

1. Mori, K.; Bariani, P.F.; Behrens, B.A.; Brosius, A.; Bruschi, S.; Maeno, T.; Merklein, M.; Yanagimoto, J. Hot stamping of ultra-high strength steel parts. Cirp. Ann-Manuf. Technol. 2017, 66, 755-777. [CrossRef]

2. Karbasian, H.; Tekkaya, A.E. A review on hot stamping. J. Mater. Process. Technol. 2010, 210, $2103-2118$. [CrossRef]

3. Ying, L.; Zhao, X.; Dai, M.H.; Zhang, S.Z.; Hu, P. Crashworthiness design of quenched boron steel thin-walled structures with functionally graded strength. Int. J. Impact Eng. 2016, 95, 72-88. [CrossRef]

4. Merklein, M.; Wieland, M.; Lechner, M.; Bruschi, S.; Ghiotti, A. Hot stamping of boron steel sheets with tailored properties. J. Mater. Process Technol. 2016, 228, 11-24. [CrossRef]

5. Omer, K.; George, R.; Bardelcik, A.; Worswick, M.; Malcolm, S.; Detwiler, D. Development of a hot stamped channel section with axially tailored properties-experiments and models. Int. J. Mater. 2018, 11, 149-164. [CrossRef]

6. Vrolijk, M.; Lorenz, D.; Porzner, H.; Holecek, M. Supporting lightweight design: Virtual modeling of hot stamping with tailored properties and warm and hot formed aluminium. Procedia Eng. 2017, 183, 336-342. [CrossRef] 
7. Chokshi, P.; Dashwood, R.; Hughes, D.J. Artificial neural network (ANN) based microstructural prediction model for 22MnB5 boron steel during tailored hot stamping. Comput. Struct. 2017, 190, 162-172. [CrossRef]

8. Mu, Y.; Wang, B.; Zhou, J.; Huang, X.; Li, X. Hot stamping of boron steel using partition heating for tailored properties: Experimental trials and numerical analysis. Metall. Mater. Trans. A 2017, 48, 5467-5479. [CrossRef]

9. Bardelcik, A.; Worswick, M.J.; Winkler, S.; Wells, M.A. A strain rate sensitive constitutive model for quenched boron steel with tailored properties. Int. J. Impact Eng. 2012, 50, 49-62. [CrossRef]

10. Li, F.F.; Fu, M.W.; Lin, J.P. Effect of cooling path on the phase transformation of boron steel $22 \mathrm{mnb} 5$ in hot stamping process. Int. J. Adv. Manuf. Technol. 2015, 81, 1391-1402. [CrossRef]

11. Omer, K.; Kortenaar, L.; Butcher, C.; Worswick, M.; Malcolm, S.; Detwiler, D. Testing of a hot stamped axial crush member with tailored properties experiments and models. Int. J. Impact Eng. 2017, 103, 12-28. [CrossRef]

12. Zhou, M.B.; Tang, J.L.; Yang, J.; Wang, C.Y. Tailored properties of a novelly designed press hardened 22MnMoB steel. J. Iron Steel Res. Int. 2017, 24, 508-512. [CrossRef]

13. Mu, Y.H.; Wang, B.Y.; Zhou, J.; Kang, Y.; Li, X.T. Heating parameters optimization of hot stamping by partition heating for tailored properties. ISIJ. Int. 2017, 57, 1442-1450. [CrossRef]

14. Nakagawa, Y.; Mori, K.I.; Maeno, T. Springback-free mechanism in hot stamping of ultra-high-strength steel parts and deformation behaviour and quenchability for thin sheet. Int. J. Adv. Manuf. Techol. 2018, 95, 459-467. [CrossRef]

15. Krinninger, M.; Opritescu, D.; Golle, R.; Volk, W. Experimental investigation of the influence of punch velocity on the springback behavior and the flat length in free bending. Procedia CIRP 2016, 41, 1066-1071. [CrossRef]

16. Bao, J.; Liu, H.; Xing, Z.; Song, B.; Yang, Y. Springback of hot stamping and die quenching with ultra-high-strength boron steel. Eng. Rev. 2013, 33, 151-156.

17. Barcellona, A.; Palmeri, D.; Worswick, M. Hot forming of boron steels using heated and cooled tooling for tailored properties. Metall. Mater. Trans. A 2009, 40, 1160-1174. [CrossRef]

18. Merklein, M.; Svec, T. Effect of plastic hot deformation on the hardness and continuous cooling transformations of 22MnB5 microalloyed boron steel. In Proceedings of the 29th IDDRG International Conference, Graz, Austria, 31 May-2 June 2010.

19. Nikravesh, M.; Naderi, M.; Akbari, G.H. Transformation kinetics of the hot stamping steel $22 \mathrm{MnB5}$ in dependency of the applied deformation on the austenitic microstructure. Mater. Sci. Eng. A Struct. 2012, 540, 24-29. [CrossRef]

20. Shipway, P.H.; Bhadeshia, H.K. The effect of small stresses on the kinetics of the bainite transformation. Mater. Sci. Eng. A Struct. 1995, 201, 143-149. [CrossRef]

21. George, R.; Bardelcik, A.; Worswick, M.J. Hot forming of boron steels using heated and cooled tooling for tailored properties. J. Mater. Process Technol. 2012, 212, 2386-2399. [CrossRef]

22. Bardelcik, A.; Salisbury, C.P.; Winkler, S.; Wells, M.A.; Worswick, M.J. Effect of cooling rate on the high strain rate properties of boron steel. Int. J. Impact Eng. 2010, 37, 694-702. [CrossRef]

23. Åkerström, P.; Oldenburg, M. Austenite decomposition during press hardening of a boron steel-computer simulation and test. J. Mater. Process Technol. 2006, 174, 399-406. [CrossRef]

(C) 2019 by the authors. Licensee MDPI, Basel, Switzerland. This article is an open access article distributed under the terms and conditions of the Creative Commons Attribution (CC BY) license (http://creativecommons.org/licenses/by/4.0/). 